\title{
English Speech Acts of Illocutionary Force in Class Interaction
}

\author{
Bahing $^{1 *}$, Emzir $^{2}$, Zainal Rafli $^{2}$ \\ ${ }^{1}$ English Education Study Program, Faculty of Teacher Training and Education, Palangka Raya University, Faculty of Teacher Training \\ and Education, Palangka Raya University Yos Sudarso Street, Palangka Raya - Central Kalimantan, Indonesia \\ ${ }^{2}$ Linguistics, Jakarta State University Rawamangun Muka Street, RT.11/RW.14 Jakarta State University, East Jakarta, 13220 Indonesia
}

Corresponding Author: Bahing, E-mail: bahingparay@gmail.com

\begin{tabular}{l} 
ARTICLE INFO \\
\hline Article history \\
Received: February 21, 2018 \\
Accepted: April 29, 2018 \\
Published: June 30, 2018 \\
Volume: 9 Issue: 3 \\
Advance access: May 2018
\end{tabular}

Conflicts of interest: None

Funding: None

\author{
Key words: \\ Speech Act, \\ Illocutionary Force, \\ The Grice's Maxims, \\ Cooperative Principles, \\ Class Interaction, \\ Ethnography of Communication
}

\begin{abstract}
The goal of research was to achieve a deep comprehension of English speech acts of illocutionary force. The method applied was ethnography of communication. In relation with an approach, I applied the qualitative one. In the data collection procedures, I applied the ethnography method, i.e. field observation, recording, transcription, interview, and field notes. In analyzing the data, I used the model of communication analysis, such as analysis of: communication situation, communication events, and communication acts. The findings showed that (1) the realization of speech acts of illocutionary directive had been the dominant one, (2) the realization of Grice's maxims had been conducted "Good" as shown by the achievement index of $78.431 \%$, while the hit of maxims reached the index of $21.569 \%$, (3) the realization of direct and indirect speech acts proved that the question intonation (Ok?, No?, Here?, Clear?, Really?), question marks (What, Who, Where, When, Which, How), question words (Are, Is, Am, Can, May, Will, Shall), and the verbal ones (Explain!, Give Comment!, Give Example!, Look at!) were used significantly, (4) the use of direct speech acts was more dominant than the indirect speech acts, (5) the hit of Grice's maxims of cooperative principles in speaking occurred, such as hit of the maxims: quality, and manner, (6) the most significant finding was the illocutionary speech act of directive owned higher social status than the illocutionary assertive, (7) lastly, the use of speech act was highly determined by the contexts of situation and social cultures.
\end{abstract}

\section{INTRODUCTION}

This research was highly related to English speech acts focused on illocutionary force conducted in the class interaction of English Education Study Program. The study was specifically emphasized on the illocutionary forces of (1) representative-assertive and directive, (2) Grice's maxims of cooperative principles, (3) direct and indirect speech acts, and (4) the hit of Grice's maxims of cooperative principles in speaking.

Speech act is one of language aspects that are functional, observable, workable, concrete and empirical. Speech act is a "locomotive" to move a language or as a "trigger kit" to make a language functional in communication. Speech act is an utterance used by a speaker to make a piece of spoken language (utterance). Speech act is an ability of talking to convey, to promise, to ask, to demand, to command, to request, to deny, to complain, and to announce. It is a functional basic unit used in communication. It is the nature of language as a means of communication for doing things and working among people in the world.

Specifically, this investigation was in concern with English speech acts of illocutionary force, i.e. assertive and directive. Speech act is one of language skills that are essential in people's communication. Speech act is a "locomotive" to move a language or as a "trigger kit" to make a language functional in communication. Language works in a "silent network system" through the speech acts to produce utterances. Speech act is an utterance as a functional basic unit used in communication.

This research was mainly focused on English speech acts introduced through illocutionary force of assertive and directive established in the class interaction. Speech act is one of language skills that are functional, observable, workable, and empirical. Speech act is an "activity of talking" or in other words, speech acts is "a piece of spoken language". In more complete notion, speech act is "the act or power of speaking". It is a "spoken language" by referring to a contemporary English dictionary (Longman Dictionary, 1978:1073). It is "a tool" to move a language or as a "trigger kit" to make a language functional for doing things and working. Speech act is an utterance used by a speaker to make a piece of spoken language (utterance). Speech act is an ability of talking to convey, to promise, to ask, to demand, to request, to deny, to complain, and to announce. It is a functional basic unit used in communication. Therefore, the teaching of speech 
act is a "must" in speaking a language as stated by Zhao and Throssell (2011). This is one of the rational reasons why I had done this research of English speech acts of illocutionary force of representative-assertive and directive.

Richards and Platt (1992: 342) stated that a speech act is "an utterance as a functional unit in communication". A speech act is one of language aspects that functional, concrete, and observable. A language is abstract while speech or utterance is observable through the perspective of speech organs and its act of communication. This concept plays its prime role in this research.

Shams and Afghari (2011) indicated that "people do not produce the grammatical utterances and words merely to express themselves, they perform actions via these utterances". This finding based on the "Speech Acts of Indirect Request", which did not investigated illocution speech act, the Grice's maxims, direct speech acts, indirect speech acts, and the hit of the Grice's maxims. The difference of focus was on the "Speech Acts of Indirect Request", where mine included the sub-focuses of illocution, direct speech acts, indirect speech acts, the Grice's maxims, and the hit of the Grice's maxims.

The teaching of speech act theory "has become increasingly imperative" and "speech act theory plays its significant part in EFL teaching and learning" (Zhao and Throssell, 2016). This is one of the rational reasons why I had done this research. However, they did not focus on a certain classifications, such as locution, illocution, and perlocution. Pradiptia, et al (2013) investigated various illocutionary act that investigated judges's narratives on an Indonesian television show. The study focused on language politeness of Brown-Levinson theory. On the other hand, my research focused on the realization and the hit of maxim of cooperative principle of Grice's theory.

Speech act has advanced significantly in pragmatics (Agbedo, 2008; Dylgjeri, 2017. Pragmatics studies speech acts in context of social cultures. However, pragmatics itself cannot afford to manage speech act without the involvement of discourse for both of them are closely related (Dylgjeri, 2017). The researcher stated that "However, pragmatics cannot be fully studied without taking in consideration discourse analysis, since they are closely linked with each other". Similarly, Akinwotu (2013) had confirmed the similar reality during his studied on the relationship of speech act as a strategic means of people mobilization in political campaign for president election. Related research was Agbedo (2008) who conducted research on a speech act analysis of political discourse in the Nigerian print media. The other interesting research was the speech act of the judges in the Indonesian television show (Pradiptia et. al, 2013).

This study owned a similarity with this research in terms of illocutionary acts. The distinction was on the focus of study, where Pradiptia et al (2013) explored language politeness of Brown-Levinson theory, while this study was on the realization and the hit of maxim of cooperative principles in speaking of Grice's maxims theory. Those research were mainly on the political discourse of a public domain. On the contrary, this research focused on the realization of English speech acts of illocutionary forces, such as (i) assertive and (2) directive.
This research problem was initiated from the pre-identification of a social and empirical phenomenon in the students' circumstances. That phenomenon was mainly concerned the hit of the maxims of cooperative principles in speaking of the Grice's maxim theory (Grice, 1989:28). Interestingly, when it was obsereved, the phenomenon occurred in the students circumstances of language education department. This fact had attracted my curiosity to understand deeply and to get inform about the roots of the problem. Furthermore, this problem had never been investigated in an academic research, particularly in English Education Study Program, Faculty of Teacher Training and Education, Palangka Raya University.

The focus of investigation concerned English speech acts of illocutionary force specified in the class interaction. In particular, the sub-focuses included the speech acts of illocutionary force of assertive and directive, Grice's maxims, direct speech act, indirect speech act, and the hit of Grice's maxims of cooperative principles in speaking. The main aim of this research was to reveal the realization of English speech acts of illocutionary force in the class interaction conducted by the students of English Education Study Program, Faculty of Teacher Training and Education, Palangka Raya University. The goals were to gain deeper understanding of English speech acts, specifically the illocutionary speech act of representative-assertive and directive, direct speech act, indirect speech act, Grice's maxims of cooperative principles, and the hit of Grice's maxims of cooperative principles in speaking.

Then, the research questions were as follows:

(1) How was the realization of English speech act of illocutionary force, i.e. representative-assertive and directive?

(2) How was the realization of direct and indirect speech acts?

(3) How was the realization of Grice's maxims of cooperative principles in speaking?

(4) How far was the hit of Grice's maxims of cooperative principles in speaking?

\section{LITERATURES REVIEW}

In terms of literatures review, I reviewed many concepts of speech act basic theories. One of the concepts was initiated by a linguist, John Austin. Thereby, this research applied the speech act basic theory of the linguist Austin (1962). Furthermore, I based it as well on Searle's speech act basic theory (Searle, 1969). Finally, I assessed the maxims of cooperative principles in speaking of the Grice's maxim theory (Grice, 1989:28).

The classification of speech act comprises two kinds, i.e. (1) constative speech act and (2) performative speech act. The performative act was classified by Austin (1962) into, (1) locutionary act, (2) illocutionary act, and (3) perlocutionary act. A speaker produces utterance to make an act of doing things, means that an utterance will be followed by an act of doing things, called "Speech Act". This utterance is termed "Performative", whereas the utterance that only gives information is termed "Constative" (Embugushiki, 2010). Speech act theory of Austin (1962), Searle (1969) and Grice (1975) viewed language from the perspective of social action and 
realized it in the speech act theory and Grice's maxims of cooperative principles in speaking.

A language, as a system has a direct relation to a speech act and they work collaboratively in a functional network system, that I named it "an integrated functional network system". This indicates factually that a language works in a speech act to produce utterance. Speech act is an utterance, as a basic unit used in functional communication. Shortly speaking, speech act or utterance is considered as a real means of communication for interacting and working among people in the world.

A language works in a "silent network system" through the cognitive system to produce a concrete, observable and empirical speech or utterance. Then, this speech or utterance function as a means of social communication for working and interacting. Next, this system works in a speech act, called "speech act network system" through the human speech organs to produce speech or utterance as a means of functional communication. for working and interacting. In conclusion, the nature of a language is the "Speech Act", a functional basic unit used in communication.

Speech act is a complete language unit that consists of skills and components. It is part of language skill for it is spoken and uttered, but it is non-language components as well since it involves a speaker, topic, goal, messages, and contexts of situation and cultures. Speech act and utterance derive from non-linguistic study, but it is part of social cultures and it is an object of pragmatics (Hindawi, et. al. 2014). A basic unit of communication is speech act or utterance. When doing communication ones will make speech or utterance and that the speech is "a functional communication unit". This explication has been confirmed in Austin basic theory that "speech act is an utterance as a functional unit in communication” (Richards \& Platt, 1992: 342).

Speech act theory is in line with a concept of real communication through the context of situation and context of social cultures. Speech act theory explains how people use it and perform it in a communicative action and then how people understand what is uttered (Altikriti, 2011). In that case, the researcher focused his research on "Speech act theory attempts to explain how speakers use language to accomplish intended actions and how hearers infer intended meaning from what is said". His research concerned the application of pragmatics in the speech act analysis, particularly "indirect speech acts" in short stories. The research was written textbased, while this research was on "a live-interactive class" in the perspective of communication ethnography research. In other words, it is an ethnography of speech acts, that is how to frame speech act for doing things, interacting and working among peoples of the world. It is how to use a language for negotiation and transactions of Goods, Services and Information in the family, society, office, market, department stores.

Jabber, and Jinquan (2013) stated that "Speech is power in itself. The most significant thing in speech is the message that the speaker wants to convey. When the hearer understands the function of the message he will responds or behaves positively". Their research was due to "speech act of request: Can, Will, Must", especially the modal verbs in the political speech of the former US president of, Barak Obama. Their research was text-based research while mine was communication ethnography research in live-interactive class.

Speech act is the object of pragmatics focused on "illocutionary force" that involves the function of imagination, manipulation, creation, dynamic, and heuristics. Speech act is also part of sociolinguistics, such as dialect or language variation in a social culture context of the speakers. In this matter, a speech act theory clarifies that while speaking a speaker is doing things as well, for instances: apology, thanks, asking, complain, denial (Zayed, 2014). The researcher conducted the investigation of speech acts, such as: "apology, compliment, greeting, request, and thanking". The method applied was descriptive using "observation checklist". It was distinctive than mine that emphasized the communication ethnography research related to the realization of maxims of cooperative principles in Grice's theory.

This research was also due to the theory of Hymes in "Ways of Speaking" (Hymes, 1989:4). Then Muriel Saville-Troike, (2013:23) "The Ethnography of Communication" and Grice's theory, 1967 (Troike, 2003: 23). Then, the method and procedures applied were due to Hymes' theory of communication ethnography (1989) and developed by Troike (2003) in "Ethnography of Speaking". Next, I related it to the Grice's theory of "maxims of cooperative principles in ethnography of speaking". This Grice's theory of the maxims of cooperative principles of speaking was one of the sub-focuses of this research.

Another theory applied in this research was a pragmatic theory, for speech act is studied in pragmatics and discourse. Dylgjeri (2017) stated that "Speech Acts theories have been a considerable revolution in the development of pragmatics as a discipline. However, pragmatics cannot be fully studied without taking in consideration discourse analysis, since they are closely linked with each other".

Then, I also based this research on the pragmatic theory developed by a linguist, Leech (1993). In methodology, I accommodated the theory of "Ethnography of Communication" model of Hymes, (1989), then completed through the theory of "Ethnography of Communication" model of Troike, (2003). I also added a theory of Schiffrin, 1994 dealing with the explanation of "SPEAKING Grid" of ethnography of communication (Schiffrin, 1994:142) and the theory of ethnography research for data gathering of, Spradley, 1980 (Spradley, 1980:119).

\section{METHOD}

This research was considered a social research based on the language speakers, means that it was related to people's beliefs, social values and cultures in communication. Since this research was related to the ways people use a speech act, thereby the method used was "Ethnography of Communication" method. This method emphasized the way people use language through speech acts for a functional communication. Speech act is the nature of language, since a language is less significant without speech acts.

In line with the scope of research, thereby the size of research was simplified to be a micro ethnography research. 
The research was conducted in the Language Education Department of English Study Program in Palangka Raya University during December 2016 to April 2017. Then, the applied approach was a qualitative approach since it was related with the behavior of doing communication through speech acts. The types of data needed were a data of narrative-descriptive.

The procedures of collecting the data, I referred to theory of Spradley (1980) in terms of ethnography research which is based on field research or field work. The procedures involved these procedures, such as: (1) observation, (2) recording, (3) interview, (4) transcription, and (5) documentation or field notes. In this matter, there were 10 records of class interactions that used in the data analysis.

This research based on the communication ethnography, and that is why I dealt with the theory of Hymes (1989), particularly on the analysis of communication. This theory was also developed further by Troike (2003) in concern with the steps and procedures, i.e. (1) analysis of communication situation, (2) analysis of communication events, and (3) analysis of communication act.

The elicited data were field data, such as observation, interaction records, transcriptions, interviews, and the documentation such as photo, video/film, and field notes. Then, the resources of data were elicited from the interaction of lecturer(s) and students in several interactive classes through live event interaction.

\section{RESULTS AND DISCUSSION}

\section{Results}

The research recorded about 220 interaction events between the lecturers and students. In that interaction, the lecturer(s) completed 130 events, while students completed 90 events of interaction. This result showed the index of lecturers' dominance was $59.09 \%$ whereas the students were $40.91 \%$. Therefore, it implied that lecturer(s) showed a more dominant position in that class interaction.

The interaction events produced 51 speech events. Then after an analysis of data, it was identified that eleven (11) of speech events were failed to be done completely. This failing was due to the fact that the students never learned how to carry out the speech act for an interaction. The achievement index falled under category "good" based on performance index of $78.431 \%$. The failing index of $21.569 \%$ was due to the hit of Grice's maxims of cooperative principles in speaking. Moreover, the students never learned about the Grice's maxims theory, before. It meant that they hit the Grice's maxims theory due to the lack of information about it. This fact was identified through the class observation and interviews with the students and the lecturers.

(1) This research found that the realization of speech acts in an interactive class has been conducted "good", where students active-participated in their contribution of interaction. The significant finding proved that the illocution speech act of directive has become the dominant one in that interaction. Then, the second dominant one was illocution speech act of representative-assertive used by lecturer(s) and students in that interaction. The research found that the lecturers mostly used illocution speech act of directive one. This fact elicited interpretation that the illocution speech acts of directive one plays the most significant roles in that interaction. This interpreted that this illocution speech act of directive has high social status. This was the most significant finding of the research and this considered as the newness of the research. Then, the finding proved that the students mostly used the illocution speech act of representative-assertive one. This finding interpreted that the speech acts of illocution: representative-assertive has become the second dominant one and it has a lower social status than that of the illocution speech act of directive one.

(2) The findings showed that direct speech acts play the dominant role in that interaction. In this finding, the lecturer(s) and students mostly used direct speech acts. They used (1) question intonation, such as: ((Right?, Yes?, No?, You?, Clear?, Finish?), (2) interrogative clauses, such as: (Is, Are, Do, Can, Will, Shall, Does, Did), (3) question words, such as (What, Where, When, Who, Which, and How), and verbal words, such as (Explain!, Give Example!, Listen!). The result of research proved that the use of speech acts was highly determined by the contexts of speech event and the situation around it. This research had found that speech act was closely related with the context of situation and context of social cultures. It was identified through this investigation where the dominant one kept control the class interaction. The dominant one was the higher social status (lecturer) and the lower one was the students. The higher social status (lecturer) mostly applied speech acts of illocutionary directive.

(3) The next finding was about the realization of Grice's maxims of cooperative principles in speaking. This research found that the realization of speech acts in an interactive class had been categorized as "Good", whereas most students actively participate in the class interaction. The finding indicated that the realization of Grice's maxims has been implemented in good achievement by the index of 78.431 $\%$ (Good mastery level). It interpreted that the participants could make good contribution and become active-participants in that interaction.

The students provide positive participation and contribution to the class interaction. In average, the performance index lied in $78.431 \%$ according to mastery level index, where 80-100 (Very Good), 75-79 (Good), 70-74 (Fair), 60-69 (Less), 50-59 (Poor), 00-49 (Very Poor). This implied that the participants could share information and provided contribution to the lecturer(s) in that interaction through the use of English speech acts. The performance index (78.431\%) derived from the number of 51 communication events, where 11 speech events failed and 40 speech events succeeded.

(4) The finding also proved that there was a hit of Grice's maxims of cooperative principles in speaking. This provided interpretation that there were students failed to give contribution because of doubtful, confuse, lack of information, miss-understanding, and keep silent. This situation made them hit the Grice's maxims, especially the maxim of manner. But however, lecturers also hit the Grice's maxims due to some interruptions without prior apology to the floor. Many times, lectures cut the students' interaction and did not 
provide any longer chance for the students to give a longer contribution.

The failure index of $21.569 \%$ was due to the hit of Grice's maxims of cooperative principles, such as maxims of quality and manner. This failure was recognized through the interaction between students and lecturer(s), where there was not enough cooperation and communication between the two parties. The lecturer(s) often cut the interaction and made some interruptions without prior permission to the class. The lecturer(s) cut the students' talks and did not provide any longer opportunity to students to talk more. More over, the research found that some students could not provide their contributions to lecturer(s) or class since they could not find the fact of the answers. Then, the students (class) kept silent, no communication. This had caused a hit to the Grice's maxims of cooperative principles in speaking.

\section{DISCUSSION}

The results of investigation indicated that the mastery index made by the participants was "Good" in the realization of English speech acts of illocution in the class interaction to the students of English Education Study Program, Faculty of Teacher Training and Education, Palangka Raya University. As a standing point, I would say that the realization of English Speech acts in terms of illocution speech acts, Grice's maxims of cooperative principles in speaking, direct and indirect speech acts, and the hit of Grice's maxims was in "Good" achievement with average index of $78.431 \%$. It was due to the level of mastery index, where 80-100 (Very Good), 75-79 (Good), 70-74 (Fair), 60-69 (Less), 50-59 (Poor), 00-49 (Very Poor).

\section{The realization of english speech acts of illocutionary force}

Theoretically, illocution speech act is a functional basic unit in communication. This was indicated in the class interaction where students and lecturer(s) were active of giving and demanding of information and contribution to the class interaction.

The research finding indicated that the illocution speech act of directive has become the most dominant one, while illocution speech act of representative-assertive one became the second dominant one. This finding indicated that lecturers and students could carry out class interaction through dialogue of questions and answers. In this finding, students were active in giving contribution as well as possible as in "When we speak we do mean exactly what we say" Ma (2016). The realization of English speech acts of illocutionary force, such as representative-assertive and the directive one had reached the completion of $100 \%$. It had been conducted proportionally where illocutionary speech act of directive was more dominant with $59.09 \%$ than the illocutionary speech act of representative-assertive of $40.91 \%$. This signified that the participants could provide contribution and give responds to the lecturers' questions and requests.

The research finding indicated that the illocution speech act of directive had become the most dominant one (59.09\%), while illocutionary speech act of representative-assertive one had become the second dominant one (40.91). This finding indicated that lecturers and students could carry out class interaction through dialogue of questions and answers. In those interactions, the lecturer(s) guided the class through illocutionary speech acts, but in that case the most dominant one was the illocutionary speech act of directive one. Most of the time in the class interaction, the lecturer(s) applied the illocutionary speech acts of directives for asking, requesting, complaining, giving and demanding students' contributions.

The most significant finding of this research was that the illocutionary speech act of directive had become the dominant one of achievement average index (59.09\%), where illocutionary speech act of assertive-representative became the second dominant one $(40.91 \%)$. The lecturer(s) mostly applied the illocutionary speech act of directive one. The lecturer (s) were regarded as one of the higher class in the speech act classification. Therefore, this finding provided an interpretation that the illocutionary speech acts of directive dominated by a higher social status than other speech act classifications in interactive communication.

In this finding, students were active in giving contribution as well as possible as in "When we speak we do mean exactly what we say". This was in line with study conducted by Ma (2016). The results indicated that the mastery index made by the participants was $59.09 \%$ the more dominant of illocutionary speech act of directive, than the illocutionary speech act of assertive of $40.91 \%$ in the realization of English speech acts of illocutionary force in the class interaction to the students of English Education Study Program, Faculty of Teacher Training and Education, Palangka Raya University. Theoretically, illocution speech act is a functional basic unit in communication. This was indicated in the class interaction where students and lecturer(s) were active of giving and demanding of information and contribution to the class interaction.

The finding of research proved that the use of speech acts of illocutionary force, such as representative-assertive and directive was highly determined by the context of situation and context of social values and cultures of the speech act speakers. In this occasion, the lecturer(s) represented the higher social status of the speaker(s), while the students represented the lower social status of the speaker(s).

\section{The realization of direct and indirect speech acts}

The findings showed that direct speech acts played the most dominant role in that interaction. In this finding, the lecturer(s) and students mostly used direct speech acts. They used (1) question intonation, such as: ((Right?, Yes?, No?, You?, Clear?, Finish?), (2) interrogative clauses, such as: (Is, Are, Do, Can, Will, Shall, Does, Did), (3) question words, such as (What, Where, When, Who, Which, and How), and verbal words, such as (Explain!, Give Example!, Listen!) were all used significantly. Thereby, the result of research implied that the direct speech acts was more dominant than indirect speech acts.

The realization of direct and indirect speech acts has been established well enough. This has been proven through the 
use of (question intonation, question words, interrogatives, and verbal verbs). The use of direct and indirect speech acts were in line as the finding by Istiningdias et. al (2014). They found that "Direct speech act was to refer to clause in which the mood of the clause matches the speaker's intent in this way. Indirect speech act mood and the speaker's intent do not always match".

The rational interpretation of using direct speech act was due to the effectiveness and efficiency of time used in an interaction. Thereby, in this realization both parties frequently used the direct speech acts rather than the indirect speech acts. Next, the use of indirect speech act was more complex than the direct speech acts.

\section{The realization of Grice's maxims of cooperative principles in speaking}

The failure index of $21.569 \%$ was due to the hit of Grice's maxims of cooperative principles, such as maxims of quality and manner. This failure was recognized through the interaction between students and lecturer(s), where there was not enough cooperation and communication between the two parties. The lecturer(s) often cut the interaction and made some interruptions without prior permission to the class. The lecturer(s) cut the students' talks and did not provide any longer opportunity to students to talk more. More than that, the research found that some students could not provide their contributions to lecturer(s) or class since they could not find the fact of the answers. Then, the students (class) kept silent, no communication. This had caused a hit to the Grice's maxims of cooperative principles in speaking, such as maxim of manner. But however, the participants of that class interaction were still be compatible to achieve "Good" performance as shown by the average achievement index of $78.431 \%$.

In line with the goal of research, I would confirm that a good understanding of speech acts could guide a speaker to be a dominant party in an interaction, such as the finding of this research. A person with good basic competence of speech acts such as illocution speech act would be a good speaker in a conversation, discussion, dialogue and debate. The goal of this research had been achieved where speech acts was identified as a functional basic unit in meaningful communication. Then, the use of speech act was highly related with the context of situation and the context of social cultures of the speaker(s), such as the result of this study. Then, the good understanding of illocutionary force showed that the illocution speech act of directive one has a higher social status in conversation when compared to other speech act classifications, such as assertive, commisive, expressive, and declarative.

\section{The hit of Grice's maxims of cooperative principles in speaking}

In discussing Cooperative Principles, Grice subdivided the general principle into the more detailed and explicit maxims. There are four maxims: Quantity Maxim, Quality Maxim, Relation Maxim, and Maxim Manner" (Ma, 2016) The result of research provided some hits towards the realization of Grice's maxims. The hit of the maxim reached the index of $21.569 \%$. This finding was in accordance with the basic assumption previously mentioned.

In field observation, it was identified that students could not find the fact of the answers which made the class silent because of no communication and no information for a meaningful contribution. This situation made the class could not say anything and they could not convey anything to the class. This was an interesting phenomenon to be investigated for the next coming research of another researcher(s). It was identified that the class did not recognize an adequate strategy in speaking, especially in discussion, dialogue, and conversation. In other words, the class could not understand the way how to make a conversation active and live through the application of illocutionary speech acts. More than that the lecturer(s) did not give enough time for students to talk more about their contributions to the class, and the lecturer(s) directly cut the moments of talks without prior apology. This hit the maxim of manner of Grice's maxims theory.

The result of research explained that the realization of English speech acts of illocutionary force in an interactive class had been carried out and it reached an achievement index of "Good", because it proved the students actively joined the class. The students could provide their contribution to the class. It was indicated by their achievement average index of $78.431 \%$ according to mastery level index. This implied that the participants could share information and provided contribution to the lecturer(s) and to the class in that interaction through the use of English speech acts of illocutionary force. The performance index $(78.431 \%)$ derived from the number of 51 communication events, where 11 speech events failed and 40 speech events successfully completed.

It was identified that the class (students) never learn about how to apply speech acts for an interaction explicitly. In other words, the students never learn how to manage a strategy of speaking based on the theory of Grice's maxims of cooperative principles in speaking. It was known from field observation and interviews among the students and lecturers. It meant that the students made hits of the Grice's maxims due to the less information about it. But in this research, it was necessary to know about the realization of English speech acts in class interaction, especially the illocutionary speech acts. Theoretically, according to Searle, 1969 that illocution speech acts consist of (1) representative-assertive, (2) directive, (3) commissive, (4) expressive, and (5) declarative, but in this research, there was only assertive and directive to be investigated.

During field observation, it was identified that students could not find the fact of the answers which made the class silent because of no communication and no information for a meaningful contribution. This situation made the class could not say anything and they could not convey anything to the class. This was an interesting phenomenon to be investigated for the next coming research of another researcher(s). It was identified that the class did not recognize an adequate strategy in speaking, especially in discussion, dialogue, and conversation. In other words, the class could not understand the way how to make a conversation active and live through the application of illocution speech acts. More than that the 
lecturer(s) did not give enough time for students to talk more about their contributions to the class, and the lecturer(s) directly cut the moments of talks.

The result proved that there was a hit of Grice's maxims theory of cooperative principles in speaking. The hit of Grice's maxims due to interaction failed to be done completely and properly in that class interaction. The hit was mainly in the maxims of manner and quality. The hit of manner maxim occurred due to the cases of interruptions made by the lecturer(s), where they often cut the talks suddenly without prior apology to the class. The hit affected the class interactions that stop suddenly and the communication broken down. The hit of the maxim of manner were made by the students mainly because they had no clue of the information given, data, or knowledge to be shared in the class interaction. As the consequences, they made hit to the Grice's maxims of cooperative principles in speaking. In this situation, students hit both the Grice's maxims of quality and manner.

Maxim of quality was hit whenever the students or lecturers could not give contribution to the class interaction which mainly derived from no or miss information into the subject of the discussion. Then, maxim of manner was hit whenever the students could not contribute or participated in the class interaction. There were various reasons identifed, such as: interruptions, lose confident, having no chance to speak, shyness to utter any words or information, or scaredness of faults. Moreover, the students never learned about the Grice's maxims theory before. It meant that they hit the Grice's maxims theory due to the lack of information about it. This fact was identified through the class observation and interviews with the students and the lecturers outside the class interaction.

\section{CONCLUSION AND RECOMMENDATION}

\section{Conclusion}

(1) The finding proved that an interactive class was dominated by the illocutionary speech acts of directive. Then, it was followed by the illocutionary speech act of representative-assertive one. This finding was due to the fact that the lecturer(s) mostly applied the illocutionary speech act of directive one. Then, this finding provided an interpretation that the illocutionary speech acts of directive one has a higher social status than illocutionary speech act of representative assertive. This fact could be concluded that the use of speech acts of illocutionary force was highly related with the context of situation and the context of social cultures of the speaker(s).

(2) The direct speech acts played the most dominant one used by lecturers to give instructions. The indirect speech acts were not frequently applied. The rational of using direct speech act was due to the effectiveness and efficiency of time used in an interaction. Thereby, in this realization both parties frequently used the direct speech acts rather than the indirect speech acts.

(3) The realization of Grice's maxims of cooperative principles were in good achievement by referring to the index of $78.431 \%$, whereas the failing index was only $21.569 \%$.
This percentage interpreted that the realization of speech acts in terms of Grice's maxims had been realized "Good", even though the students never learned it before. However, the both parties, i.e. students and lecturers hit the Grice's maxims, and students' failures were due to the reality that they were still lack of knowledge (since they never learned it). Students hit the Grice's maxims through the maxims of quality and manner, while lecturer(s) hit the Grice's maxims in terms of interruptions where lecturer(s) often made cuts of the talks. Moreover, the lecturer(s) often cut the talks and did not provide any longer opportunity for the students to talk.

(4) Then, the failing index of $21.569 \%$ gave an interpretation that students did not master the strategy of conducting the speech acts in a class interaction. It was referred to the fact that students never learned about the strategy of speaking through the Grice's maxims of cooperative principles in speaking. This finding proved the previous basic assumption about the research that there was a hit of Grice's maxims of cooperative principles in speaking done by several students in English Education Study Program, and it was proved.

This failing was due to the fact that the students never learned about how to carry out the speech act for an interaction. In other words, the students did not learn about the Grice's maxims of cooperative principles in speaking, before. Thereby, the results of research proved that there were some hits of the Grice's maxims made by the students in the class interaction.

\section{Recommendation}

The knowledge of speech acts is considered essential to be taught to students, especially the illocutionary force. It is in line with the nature of language as a means of communication. As a means of communication, a language is represented by a speech act, because speech act is a basic unit in functional communication. Speech act is the nature of language for a functional communication. Thereby, learning a language is learning how to apply speech acts in communication and interaction. It is the speech acts used in transaction and negotiation of Goods \& Services, and information. Speech act is used in social relations for interacting, meaning making and social working.

The teaching of speech acts, especially the illocutionary force or illocution speech act was considered as "a must". This was in line with the result of research report by Zhao and Throssell (2011). The knowledge of speech acts is considered essential to be taught to students, especially the illocutionary force. This was in line with the finding of this research where the competence of the participants was still lower. Thereby, it was recommended to the English Education Study Program to take into account the speech act aspect to be one of course materials of speaking skill.

Next, the material of speech act in terms of Grice's maxims of cooperative principles of speaking was considered necessary to be available in the syllabus design, particularly in the course of speaking class. This matter was necessary to be managed to make the students understand the strategy of speaking through the Grice's maxims of cooperative principles. It was identified previously through the observation, 
interview, and the recording of interaction that the material of Grice's theory had never been given explicitly to the class. This indicated that the material of technique and strategy in speaking skills, such as transaction and negotiation, discussion and debate had never been given to the class. That is why, it is highly recommended to be taught as one of the instructional materials.

\section{REFERENCES}

Agbedo, Ch. (2008). A Speech Act Analysis of Political Discourse in the Nigerian Print Media. Ikenga International Journal of African Studies, 10(1\&2), 159-191. http://inguisticsafrikana.com/journal1.html

Akinwotu, S. (2013). A Speech Act Analysis of the Acceptance of Nomination Speeches of Chief Obafemi Awolowo and Chief M.K.O. Abiola. International Journal on English Linguistics Research. Adekunle Ajasin University, Nigeria. http://dx.doi.org/10.5430/elr. v2n1p43

Altikriti, S.F. (2011). Speech Act Analysis to Short Stories. Journal of Language Teaching and Research, 2(6), p 1374-1384. ttp://dx.doi.org/10.4304/jltr.2.6.1374-1384

Austin L. J. (1962). How To Do Things With Words. Oxford-UK: At the Clarendon Press.

Barbara, J., and William, M. M. (2010). Dell Hymes and the Ethnography of Communication. Carnegie Mellon University. http://repository.cmu.edu/cgi/viewcontent. cgi? article $=1013 \&$ context $=$ english

Dylgjeri, A. (2017). Analysis of Speech Acts in Political Speeches. European Journal of Social Sciences Studies, 2(2). http://doi.org/10.5281/zenodo.344518

Embugushiki, A. (2010). Doing Things with Words: A Speech Act Analysis of a Christian Wedding. African Research Review, 4(1). http://dx.doi.org/10.4314/afrrev. v4i1.58206

Grice, H. P. (1967). Logic in Conversation (California: by Harvard University Press).

Hindawi, F., Masu'di, H., Mirza, R. (2014). The Speech Act Theory in English and Arabic. Open Journal of Modern Linguistics, 4, p27-37 http://www.scirp.org/journal/ ojml. http://dx.doi.org/10.4236/ojml.2014.41003

Hymes, D. (1989). The Ethnography of Communication. Carnegie Mellon University, Pittsburgh PA, USA.

Hymes, D. (2009). Hymes's Linguistics and Ethnography in Education. Journal of Graduate School of Education, Penn Libraries: University of Pennsylvania, Scholarly Commons. http://dx.doi.org/10.1515.2009).

Istiningdias, D.S., Sujatna, E., Indrayani, L. (2014). "Illocutionary Acts In Declarative Mood: A Functional
Grammar Approach. International Journal of English and Education, 3(3).

Jabber, Kh., and Jinquan, Z. (2013). The Modal Verbs: A Speech Act of Request in the Speech of the former President of the United States, Barak Obama. Issue 12, February 2013. http://www.the-criterion.com/V4/n1/ Khalid.pdf

Ma, X. (2016). A Case Study on Characters in Pride and Prejudice: From Perspectives of Speech Act Theory and Conversational Implicature. International Journal of English Linguistics, 6(4), DOI: http://dx.doi. org/10.5539/ijel.v6n4p136

Leech, G. (1993). The Principles of Pragmatics: The Longman Group, Ltd., University of Lancaster-UK.

Longman. (1978). Longman Dictionary of Contemporary English. Longman Group, Ltd. Printed in Great Britain, at The Pitman Press, Bath.

Pradiptia, W.U., Nani Darmayanti, S.R. (2013). Expressive Speech Act of Judges' Narratives In X-Factor Indonesia Talent Show on Rajawali Citra Televisi Indonesia (RCTI): A Pragmatic Study. International Journal of Language Learning and Applied linguistics World (IJL$L A L W)$, 4(4) p543-561. http://www.ijllalw.org/finalversion4442.pdf

Richards, J. C., and Platt, P. (1992). Dictionary of Language Teaching \& Applied Linguistics: Longman Group, U.K Edinburgh, England.

Searle, J. (1969). Speech Acts: An Essay in the Philosophy of Langaguage: Cambridge: Cambridge University Press.

Schiffrin, D. (1994). Approaches to Discourse: Blackwell Publishing: 238 Main Street, Cambridge, Massachusetts-USA.

Shams, R. \& Afghari, A. (2011). Effects of Culture and Gender in Comprehension of Speech Acts of Indirect Request”. English Language Teaching, 4(4), http://dx.doi. org/10.5539/elt.v4n4p279

Spradley, P. J. (1980). Participant Observation: Orlando, Florida: Harcourt Brace Jovanovich Inc.

Troike-Saville, M. (2003). The Ethnography of Communication. Blackwell Publishing: Oxford, UK.

Zayed, N. (2014). Jordanian EFL Teachers' and Students' Practice of Speech Acts in the Classroom. International Journal on Studies in English Language and Literature (IJSELL), 2(5),01-10

Zhao, Y., and Throssell, P. (2011). Speech Act Theory and Its Application to EFL Teaching in China. Language Society and Culture. Issue $32 \mathrm{p} 88-95$. Downloaded from https://www.researchgate.net/profile/Paul_Throssell/ publication/266869217 